九州大学学術情報リポジトリ

Kyushu University Institutional Repository

\title{
Water-soluble doubly $\mathrm{N}$-confused hexaphyrin : a near-IR fluorescent $\mathrm{Zn}$ (II) ion sensor in water
}

Ikawa, Yoshiya

PRESTO, Japan Science and Technology Agency (JST)

Takeda, Mari

Department of Chemistry and Biochemistry, Graduate School of Engineering, Kyushu University

Suzuki, Masaaki

Department of Chemistry, Graduate School of Science, Kyoto University

Osuka, Atsuhiro

Department of Chemistry, Graduate School of Science, Kyoto University

他

http://hdl. hand le. net/2324/26434

出版情報：Chemical Communications. 46 (31)，pp.5689-5691，2010-08

バージョン：

権利関係: (C) The Royal Society of Chemistry 2010 


\title{
Water-soluble doubly N-confused hexaphyrin: A near-IR fluorescent $\mathrm{Zn}(\mathrm{II})$ ion sensor in water
}

\author{
Yoshiya Ikawa, ${ }^{a, b}$ Mari Takeda, ${ }^{a}$ Masaaki Suzuki, ${ }^{c}$ Atsuhiro Osuka ${ }^{c}$ and Hiroyuki Furuta ${ }^{* a}$
}

\begin{abstract}
A water-soluble doubly $\mathrm{N}$-confused hexaphyrin $\left(\mathrm{N}_{2} \mathrm{CH}\right)$ having two octa-arginine peptide arms displays an enhanced nearinfrared (NIR) emission around $1050 \mathrm{~nm}$ in the presence of $\mathrm{Zn}^{2+}$ in aqueous solution.
\end{abstract}

5 In the biomedical/bioanalytical fields, NIR-light technology has been of growing importance since the interference by biomolecules could be minimized in the NIR region. ${ }^{1}$ Among a variety of targets for NIR-biosensing, $\mathrm{Zn}^{2+}$ ion gathers wide attention because of its importance as one of the most 10 essential metal ions in the human body and the interest for the neurochemical functions. ${ }^{2}$ Previously, in a series of studies on $\mathrm{N}$-confused porphyrinoids, ${ }^{3}$ we have shown doubly $\mathrm{N}$ confused hexaphyrin $\left(\mathrm{N}_{2} \mathrm{CH}, \mathbf{1}\right.$, Chart 1$)$, a kind of expanded porphyrin, forms bis-metal complexes with various divalent 15 and trivalent metal ions such as $\mathrm{Cu}^{2+}, \mathrm{Ni}^{2+}, \mathrm{Zn}^{2+}, \mathrm{Mn}^{3+}$, and $\mathrm{Fe}^{3+}$, and displays an intensified near-infrared (NIR) emission with $\lambda_{\mathrm{em}}>1000 \mathrm{~nm}$ in $\mathrm{CH}_{2} \mathrm{Cl}_{2}$ when $\mathrm{Zn}^{2+}$ ions are coordinated. ${ }^{4}$ Since then, we have been interested in synthesizing a water-soluble derivative, which serves as a NIR 20 fluorescent sensor molecule, especially, for $\mathrm{Zn}^{2+}$ in aqueous media. Herein, we report the synthesis of a water-soluble derivative of $\mathrm{N}_{2} \mathrm{CH}$ possessing two highly hydrophilic octaarginine peptides $\left(\mathbf{N}_{\mathbf{2}} \mathbf{C H}-\mathbf{R 8}, \mathbf{4}\right)$ and its emission behaviour in the presence of various metal ions in aqueous media. A 25 largely enhanced NIR emission around $1050 \mathrm{~nm}$ in water by $\mathrm{Zn}^{2+}$ coordination was demonstrated for the first time.

Synthesis of $\mathbf{N}_{\mathbf{2}} \mathbf{C H}-\mathbf{R 8}$ was performed by conjugation of two peptides and $\mathrm{N}_{2} \mathrm{CH}$ via a $\mathrm{Cu}(\mathrm{I})$-catalyzed "click reaction" between azide groups and terminal alkynes (Scheme 1), 30 which are installed in the peptide and $\mathrm{N}_{2} \mathrm{CH}$, respectively. ${ }^{6}$ At first, $\mathrm{N}_{2} \mathrm{CH}$ derivative possessing two ethynylaryl groups (3), which was derived from meso-aryl $\mathrm{N}_{2} \mathrm{CH}$ having two 2,3,5,6tetrafluoro-4-iodophenyl groups, was synthesized through Sonogashira coupling reactions with $\mathrm{Pd}\left(\mathrm{PPh}_{3}\right)_{2} \mathrm{Cl}_{2}$ and $\mathrm{CuI}$ in ${ }_{35} 49 \%$ yield. $^{7}$ The counterpart, octa-arginine (R8) peptide derivative (5), in which the arginine side-chains were protected with 2,2,4,6,7-pentamethyldihydro-benzofuran-5sulfonyl $(\mathrm{Pbf})$ groups and its $\mathrm{N}$-terminus bears an azide

\footnotetext{
${ }^{a}$ Department of Chemistry and Biochemistry, Graduate School of Engineering, Kyushu University, Fukuoka 819-0395, Japan. E-mail: hfuruta@cstf.kyushu-u.ac.jp; Fax: +81-92-802-2865 ${ }^{b}$ PRESTO, Japan Science and Technology Agency (JST), Tokyo 102-0075, Japan.

${ }^{c}$ Department of Chemistry, Graduate School of Science, Kyoto University, Kyoto 606-8502, Japan.

$\dagger$ Electronic Supplementary Information (ESI) available: Details of the experiments, theoretical calculations and spectroscopic measurements.
}

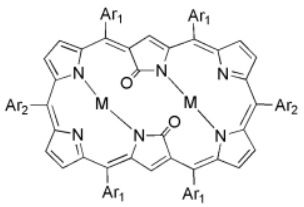

Doubly $\mathrm{N}$-Confused Hexaphyrin $\left(\mathrm{N}_{2} \mathrm{CH}\right)$

$1\left(\mathrm{Ar}_{1}=\mathrm{Ar}_{2}=\mathrm{C}_{6} \mathrm{~F}_{5}, \mathrm{M}=2 \mathrm{H}\right)$

$2\left(\mathrm{Ar}_{1}=\mathrm{Ar}_{2}=\mathrm{C}_{6} \mathrm{~F}_{5}, \mathrm{M}=\mathrm{Zn}\right)$

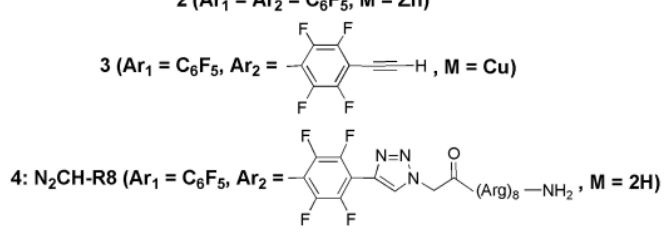

40

Chart 1 Structures of doubly N-confused hexaphyrins.

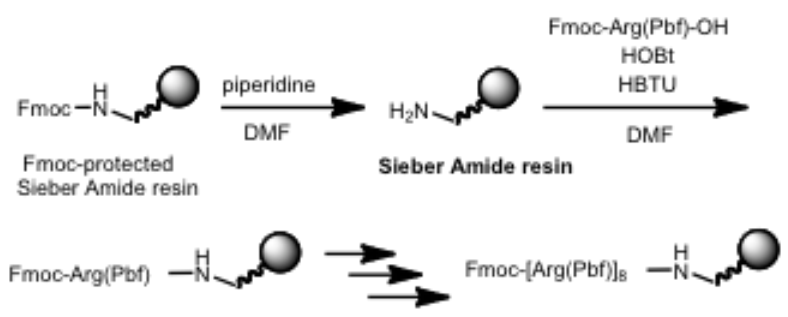

1) piperidine / DMF

2) $\mathrm{N}_{3} \mathrm{CH}_{2} \mathrm{CO}_{2} \mathrm{H}$, PyBOP, HOBt / DMF
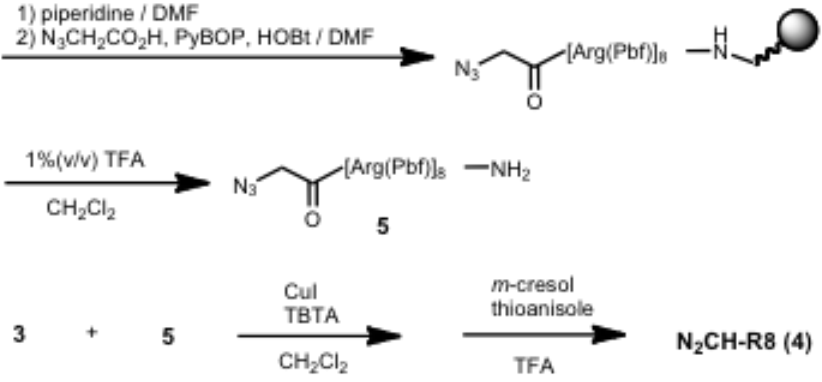

Scheme 1 Synthesis of $\mathbf{N}_{2} \mathbf{C H}-\mathbf{R 8}$ via conjugation of $\mathrm{N}_{2} \mathrm{CH}$ (3) and protected octa-arginine peptide (5) by a $\mathrm{Cu}(\mathrm{I})$-catalyzed Huisgen 1,345 dipolar cycloaddition.

moiety, was prepared by the solid-phase synthesis, which started from fluoren-9-ylmethyloxycarbonyl (Fmoc) protected aminoxanthen-3-yloxy-polystyrene resin (Sieber Amide resin). ${ }^{6,7}$ Then, $\mathrm{N}_{2} \mathrm{CH}$ derivative $\mathbf{3}$ was conjugated with so peptide 5 by $\mathrm{Cu}(\mathrm{I})$-catalyzed Huisgen 1,3-dipolar cycloadditions between the terminal alkynes in $\mathbf{3}$ and the azide moiety at the N-terminus of 5 (Scheme 1). ${ }^{7}$ The reaction mixture was treated with trifluoroacetic acid (TFA) to remove $\mathrm{Pbf}$ groups and $\mathrm{Cu}^{2+}$ ions from the arginine side-chains and 55 the macrocycle, affording the desired freebase $\mathrm{N}_{2} \mathrm{CH}$-peptide 
conjugate, $\mathbf{N}_{\mathbf{2}} \mathbf{C H}-\mathbf{R 8}$. The resulting conjugate was purified by a reverse phase HPLC with $\mathrm{CH}_{3} \mathrm{CN} / \mathrm{H}_{2} \mathrm{O}$ and obtained as a TFA salt ( $46 \%$ yield based on 3 ). By partition experiments between ultrapure water and $\mathrm{CH}_{2} \mathrm{Cl}_{2}, \mathbf{N}_{\mathbf{2}} \mathbf{C H}-\mathbf{R 8}$ was 5 selectively extracted to the aqueous phase. ${ }^{8}$

At first, we examined $\mathrm{Zn}^{2+}$ complexation of $\mathrm{N}_{2} \mathrm{CH} \mathbf{1}$ in organic solvent by spectroscopic methods. In $\mathrm{CH}_{2} \mathrm{Cl}_{2}$, UV-visNIR spectrum of 1 with excess $\mathrm{Zn}(\mathrm{OAc})_{2}$ (ca. 500 equiv) was nearly identical to that of isolated $2{ }^{6}$ For $4.0 \mu \mathrm{M}$ of $\mathbf{1}$, 10 completion of the spectral changes required $200 \mu \mathrm{M}(50$ equiv) of $\mathrm{Zn}(\mathrm{OAc})_{2}$. The observation of isosbestic points at 591, 652, 764 and $830 \mathrm{~nm}$ suggests the coordination of second $\mathrm{Zn}^{2+}$ is rather fast to afford bis- $\mathrm{Zn}^{2+}$ complex, spontaneously. ${ }^{6}$ NIR-fluorescence spectra of $\mathbf{1}, \mathbf{2}$, and $\mathbf{1}$ treated in situ with 15 excess $\mathrm{Zn}(\mathrm{OAc})_{2}$ were compared at ambient temperature. Upon adding $\mathrm{Zn}(\mathrm{OAc})_{2}$, fluorescence of $\mathbf{1}$ was enhanced approximately 10 -fold, ${ }^{6}$ exhibiting a sharp emission band around $1047 \mathrm{~nm}$, which was nearly identical to that of $\mathbf{2}$. This result indicates that in situ formation of bis- $\mathrm{Zn}^{2+}$ complex of $\mathbf{1}$ 20 proceeds almost quantitatively in $\mathrm{CH}_{2} \mathrm{Cl}_{2}$ at ambient temperature.

The structure of bis- $\mathrm{Zn}^{2+}$ complex 2 was revealed by X-ray crystallography (Fig. 1). ${ }^{\star}$ The complex shows a slightly distorted structure with a mean plane deviation of $0.0798 \AA$ 25 defined by 36 heavy atoms without oxygen in the macrocycle. The displacement of $\mathrm{Zn}^{2+}$ ion is $0.0572 \AA$ and the $\mathrm{Zn}-\mathrm{Zn}$ distance is $4.806 \AA$. One $\mathrm{H}_{2} \mathrm{O}$ molecule is coordinated at the axial position of each $\mathrm{Zn}$ atom with a $\mathrm{Zn}-\mathrm{O}$ distance of 2.038 $\AA$. The water molecule might come from the adventitious 30 moisture in the solvent and such coordination would be usual for a water-soluble derivative of $\mathbf{2}$ in aqueous media.

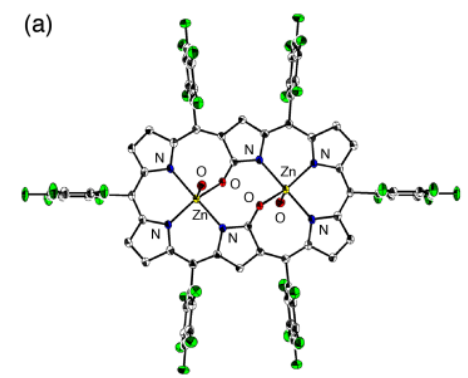

(b)

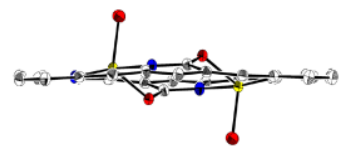

Fig. 1 ORTEP structure of 2: a) top view, b) side view. Pentafluorophenyl groups are omitted for clarity in (b). Thermal ellipsoids are shown at the $3530 \%$ probability level.

Then, $\mathbf{N}_{\mathbf{2}} \mathbf{C H}-\mathbf{R 8}$ was subjected to the spectroscopic measurements in aqueous solution (Fig. 2). The absorption $\lambda_{\max }$ values of the Soret-like (566 nm) and Q-like bands (730, $807,902,1040 \mathrm{~nm}$ ) were similar to the spectrum of $\mathbf{1}$ in DMF, 40 indicating that neither attachment of octa-arginine peptides via triazole linkers to $\mathrm{N}_{2} \mathrm{CH}$ nor aqueous media intrinsically perturbs the absorption property of $\mathrm{N}_{2} \mathrm{CH}$ macrocycle. Furthermore, in the fluorescence spectrum of $\mathbf{N}_{\mathbf{2}} \mathbf{C H}-\mathbf{R 8}$ in aqueous solution, an emission band at $1047 \mathrm{~nm}$ was observed 45 similar to $\mathbf{1}$ in $\mathrm{CH}_{2} \mathrm{Cl}_{2}(1053 \mathrm{~nm})$ as well as $\mathbf{1}$ and $\mathbf{N}_{\mathbf{2}} \mathbf{C H}-\mathbf{R 8}$ in DMF (1053 nm). The fluorescence efficiency of $\mathbf{N}_{\mathbf{2}} \mathbf{C H}-\mathbf{R 8}$ in $\mathrm{H}_{2} \mathrm{O}$ appears similar or even better than $\mathbf{1}$ in $\mathrm{CH}_{2} \mathrm{Cl}_{2}$, ${ }^{6}$ indicating that the aqueous media do not affect the fluorescence property of $\mathrm{N}_{2} \mathrm{CH}$ macrocycle adversely.

${ }_{50}$ With addition of an excess $\mathrm{Zn}(\mathrm{OAc})_{2}$ to the aqueous solution of $\mathbf{N}_{\mathbf{2}} \mathbf{C H}-\mathbf{R 8}$, the absorption $\lambda_{\max }$ of the Soret-like band shifted to $600 \mathrm{~nm}$, which is identical to that of $\mathbf{1}$ with $\mathrm{Zn}(\mathrm{OAc})_{2}$ in $\mathrm{CH}_{2} \mathrm{Cl}_{2}$. Relative fluorescence quantum yield increased 14-fold without shifting the emission maximum $55\left(\lambda_{\mathrm{em}}\right)$. Therefore, both the changes in the absorption and fluorescence spectra indicate that the $\mathrm{N}_{2} \mathrm{CH}$ macrocycle spontaneously captures $\mathrm{Zn}^{2+}$ ions in aqueous solution and its coordination mode is very similar to that of $\mathbf{1}$ in organic solvent (Fig. 2b, see also Supporting Information). The ${ }_{60}$ fluorescence spectra also indicate that $\mathbf{N}_{\mathbf{2}} \mathbf{C H}-\mathbf{R 8}$ is significantly responsive to $\mathrm{Zn}^{2+}$ in a $\mathrm{pH}$ region under neutral to weakly alkaline conditions (Fig. 2c). An excess amount of $\mathrm{Zn}(\mathrm{OAc})_{2}(800 \mu \mathrm{M}, 200$ equiv) was insufficient for rapid completion of the spectral changes with $\mathbf{N}_{\mathbf{2}} \mathbf{C H}-\mathbf{R 8}(4.0 \mu \mathrm{M})$ 65 (Fig. 2d), suggesting that the sensitivity of $\mathrm{Zn}^{2+}$ complexation of $\mathbf{N}_{\mathbf{2}} \mathbf{C H}-\mathbf{R 8}$ in $\mathrm{H}_{2} \mathrm{O}$ is several fold lower than that of $\mathbf{1}$ in $\mathrm{CH}_{2} \mathrm{Cl}_{2}$.
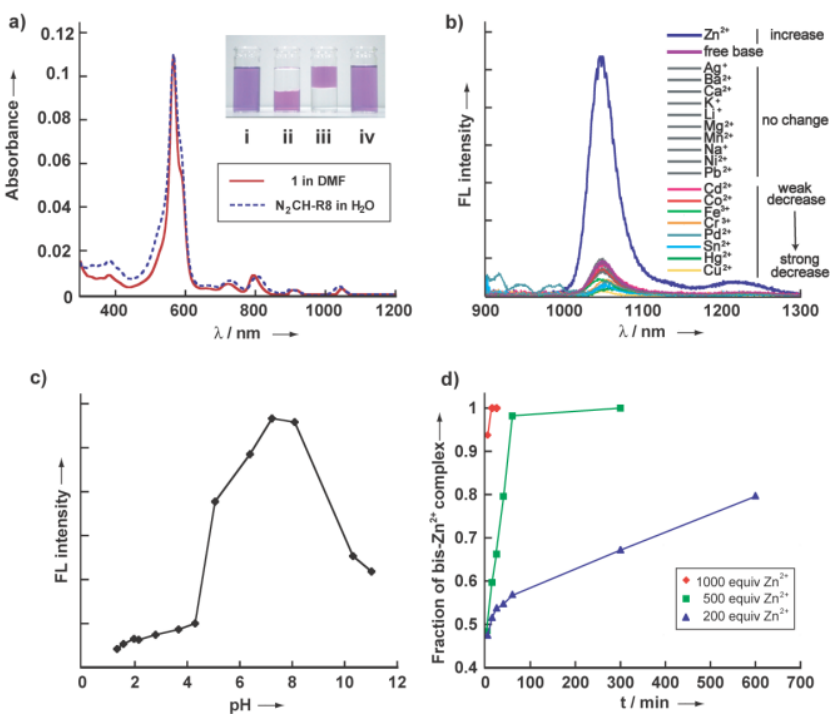

Fig. 2 (a) UV-vis-NIR spectra of $\mathrm{N}_{2} \mathrm{CH}$ (1) in DMF and $\mathbf{N}_{2} \mathbf{C H}-\mathbf{R 8}$ in $\mathrm{H}_{2} \mathrm{O}$ $70[\mathbf{1}]=\left[\mathbf{N}_{\mathbf{2}} \mathbf{C H}-\mathbf{R 8}\right]=0.27 \mu \mathrm{M}$. The inset shows partition experiments of $\mathbf{1}$ and $\mathbf{N}_{2} \mathbf{C H}-\mathbf{R 8}(6.5 \mu \mathrm{M})$. i: $\mathbf{1}$ in DMF, ii: $\mathbf{1}$ in $\mathrm{H}_{2} \mathrm{O}-\mathrm{CH}_{2} \mathrm{Cl}_{2}$, iii: $\mathbf{N}_{2} \mathbf{C H}-\mathbf{R 8}$ in $\mathrm{H}_{2} \mathrm{O}-\mathrm{CH}_{2} \mathrm{Cl}_{2}$, iv: $\mathbf{N}_{2} \mathbf{C H}-\mathbf{R 8}$ in DMF. (b) NIR fluorescence spectra of $\mathbf{N}_{2} \mathbf{C H}-\mathbf{R 8}\left(0.53 \mu \mathrm{M}, \lambda_{\mathrm{ex}}=588 \mathrm{~nm}\right)$ in $\mathrm{H}_{2} \mathrm{O}$ in the absence or presence of 1000 equiv of metal ions. (c) $\mathrm{pH}$ dependent fluorescence intensity 75 changes of $\mathbf{N}_{2} \mathbf{C H}-\mathbf{R 8}\left(0.53 \mu \mathrm{M}, \lambda_{\mathrm{ex}}=600 \mathrm{~nm}\right)$ with 1000 equiv $\mathrm{Zn}^{2+} \cdot \mathrm{pH}$ values were adjusted by aqueous $\mathrm{HCl}$ or $\mathrm{NaOH} . \mathbf{N}_{2} \mathbf{C H}-\mathbf{R 8}$ became insoluble when $\mathrm{pH}$ exceeded 11. (d) Time dependent $\mathrm{Zn}^{2+}$ coordination of $\mathbf{N}_{2} \mathbf{C H}-\mathbf{R 8}(4.0 \mu \mathrm{M})$ in $\mathrm{H}_{2} \mathrm{O}$ determined from absorption spectra.

Next, to gain insights into the complexation of other metals, 80 absorption spectra of $\mathbf{N}_{\mathbf{2}} \mathbf{C H}-\mathbf{R 8}$ were investigated in aqueous solution upon addition of 19 metal ions. Besides $\mathrm{Zn}^{2+}$, eight metal ions $\left[\mathrm{Cd}^{2+}, \mathrm{Co}^{2+}, \mathrm{Cr}^{3+}, \mathrm{Cu}^{2+}, \mathrm{Fe}^{3+}, \mathrm{Hg}^{2+}, \mathrm{Pd}^{2+}, \mathrm{Sn}^{2+}\right]$ were coordinated by the macrocycle judging from the changes of the absorption spectra. ${ }^{6}$ Among coordinated metals, only ${ }_{85} \mathrm{Zn}^{2+}$ showed a marked enhancement in emission. On the other hand, the fluorescence spectra of $\mathbf{N}_{\mathbf{2}} \mathbf{C H}-\mathbf{R 8}$ in the presence of $\mathrm{Cd}^{2+}, \mathrm{Co}^{2+}$, and $\mathrm{Fe}^{3+}$ were similar to that of freebase. In contrast, remaining five metal ions, $\mathrm{Cu}^{2+}, \mathrm{Cr}^{3+}, \mathrm{Hg}^{2+}, \mathrm{Pd}^{2+}$, and $\mathrm{Sn}^{2+}$ quenched the emission (Figs. $2 \mathrm{~b}$ and $3 \mathrm{a}$ ). ${ }^{6}$ 
Then, the effect of metal ions on the fluorescence property of $\mathrm{Zn}^{2+} \mathbf{N}_{\mathbf{2}} \mathbf{C H}-\mathbf{R 8}$ complex was examined. Metal ions (1000 equiv) that cause no effect on the absorption spectra of $\mathbf{N}_{\mathbf{2}} \mathbf{C H}$ $\mathbf{R 8}$ also did not show any change in the fluorescence spectra ${ }_{5}$ of $\mathbf{N}_{\mathbf{2}} \mathbf{C H}-\mathbf{R 8}$ with 1000 equiv $\mathrm{Zn}^{2+}{ }^{6}$ The fluorescence was not affected by $\mathrm{Cd}^{2+}$ or $\mathrm{Co}^{2+}$, whereas it was partially quenched by $\mathrm{Cr}^{3+}, \mathrm{Fe}^{3+}$, or $\mathrm{Sn}^{2+}$ and strongly quenched by 1000 equiv $\mathrm{Cu}^{2+}, \mathrm{Hg}^{2+}$, or $\mathrm{Pd}^{2+}, 6$ suggesting that the affinity of the last three metal ions to $\mathbf{N}_{\mathbf{2}} \mathbf{C H}-\mathbf{R 8}$ is comparable to or higher than 10 that of $\mathrm{Zn}^{2+}$. The strong inhibitory effect of $\mathrm{Cu}^{2+}$ ion is demonstrated by the experiment, in which $0.53 \mu \mathrm{M} \mathrm{Cu}{ }^{2+}$ quenched the fluorescence of same molar concentration of $\mathbf{N}_{\mathbf{2}} \mathbf{C H}-\mathbf{R 8}$ complex nearly completely within $30 \mathrm{~min}$ (Fig. 3b, Fig. S13). This observation suggests that the $\mathrm{Zn}^{2+}$ complex of ${ }_{15} \mathbf{N}_{\mathbf{2}} \mathbf{C H}-\mathbf{R 8}$ is also capable of serving as a "switch-off" fluorescent sensor to detect $\mathrm{Cu}^{2+}$ ions in aqueous
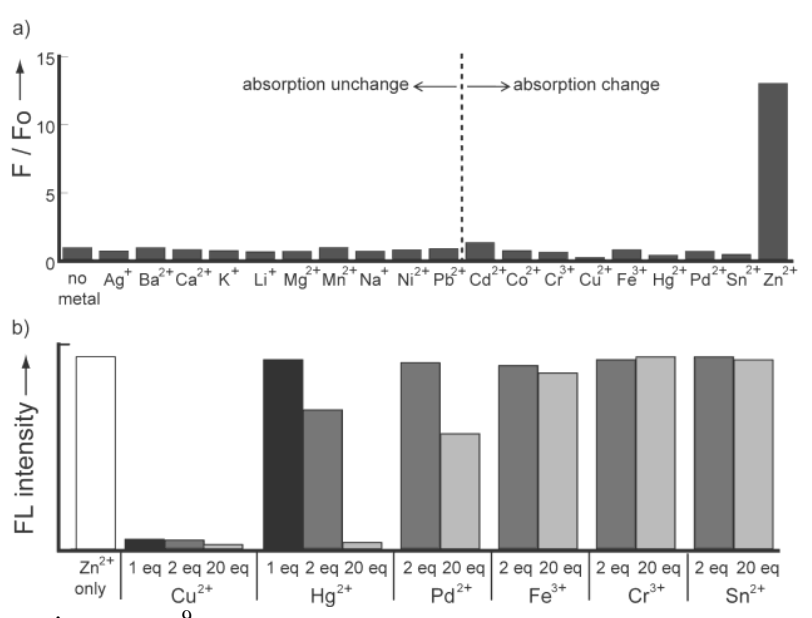

environment. ${ }^{9}$

Fig. 3 (a) Relative fluorescence intensity of $\mathbf{N}_{2} \mathbf{C H}-\mathbf{R 8}\left(0.53 \mu \mathrm{M}, \lambda_{\mathrm{em}}=\right.$ $20600 \mathrm{~nm})$ in $\mathrm{H}_{2} \mathrm{O}$ with 1000 equiv of metal ions of interest. (b) Fluorescence quenching of $\mathbf{N}_{\mathbf{2}} \mathbf{C H}-\mathbf{R 8}\left(0.53 \mu \mathrm{M}, \lambda_{\mathrm{ex}}=600 \mathrm{~nm}\right)$ with 1000 equiv $\mathrm{Zn}^{2+}$ ions by 1.0, 2.0 or 20 equiv of metal ions.

In summary, we have synthesized a water-soluble derivative of doubly $\mathrm{N}$-confused hexaphyrin $\left(\mathbf{N}_{\mathbf{2}} \mathbf{C H}-\mathbf{R 8}\right)$, 25 which exhibits enhanced NIR fluorescence around $1050 \mathrm{~nm}$ only by $\mathrm{Zn}^{2+}$ ion coordination in aqueous solution. Thus, $\mathbf{N}_{2} \mathbf{C H}-\mathbf{R 8}$ is a promising platform to develop a "switch-on" NIR fluorescent sensor for $\mathrm{Zn}^{2+}$ in aqueous solution albeit further improvement of coordination affinity and specificity, 30 as well as emission efficiency would be necessary. ${ }^{10}$ Furthermore, $\mathrm{Zn}^{2+}$ complex of $\mathbf{N}_{\mathbf{2}} \mathbf{C H}-\mathbf{R 8}$ can also serve as a promising platform for a "switch-off" NIR fluorescent sensor for $\mathrm{Cu}^{2+}$ ion, a similarly important metal ion involved in a number of biological processes in living cells. ${ }^{11}$ As octa-

35 arginine (R8) is known as a member of peptides showing a cell penetrating property that enables various molecules to be introduced into mammalian cells, ${ }^{12}$ in vivo application of $\mathbf{N}_{\mathbf{2}} \mathbf{C H}-\mathbf{R 8}$ would be of interest. Because $\mathbf{N}_{\mathbf{2}} \mathbf{C H}-\mathbf{R 8}$ would be applicable directly to in vivo analysis, investigation of its 40 photophysical and coordination properties in cultured cells is now underway.

This work was supported by Grant-in-Aids on Innovative
Areas (No. 21108518 to H.F. and No. 21111518 to Y.I.), and for the Global COE program, "Science for Future Molecular ${ }_{45}$ Systems" (to H.F.) from the Ministry of Education, Culture, Sports, Science and Technology of Japan.

\section{Notes and references}

\$. Crystal data for 2: $\mathrm{C}_{66} \mathrm{H}_{10} \mathrm{~F}_{30} \mathrm{~N}_{6} \mathrm{O}_{2} \bullet 6\left(\mathrm{C}_{4} \mathrm{H}_{8} \mathrm{O}\right) \bullet 4(\mathrm{O}), M_{\mathrm{r}}=2116.20$, monoclinic, space group $P 2_{1} / n$ (no. 14), $a=20.43(3), b=8.939(11), c=$ $5025.15(3) \AA, \beta=97.89(6)^{\circ}, V=4550(10) \AA^{3}, Z=2, \rho_{\text {calcd }}=1.545 \mathrm{gcm}^{-3}$, $\mu\left(\mathrm{Mo}_{\mathrm{K} \alpha}\right)=0.650 \mathrm{~cm}^{-1}, T=123.1 \mathrm{~K}$; Rigaku RAXIS-RAPID; 55 $>2 \theta>$ $6^{\circ}, 23026$ measured reflections, 10446 unique reflections, 5121 with $I>$ $2 \sigma(I)$ used in $F^{2}$ refinement, 632 parameters, $R=0.0666, w R=0.1920$ (all data), GOF $=0.955$. CCDC 759874 contains the supplementary 55 crystallographic data for 2.

1 (a) J. V. Frangioni, Curr. Opin. Chem. Biol., 2003, 7, 626. (b) D. P. O'Neal, L. R. Hirsch, N. J. Halas, J. D. Payne and J. L. West, Cancer Lett., 2004, 209, 171. (c) G. Reich, Adv. Drug Deliv. Rev., 2005, 57, 1109 .

2 (a) E. M. Noran and S. J. Lippard, Acc. Chem. Res., 2009, 42, 193. (b) K. Hanaoka, Y. Muramatsu, Y. Urano, T. Terai and T. Nagano, Chem. Eur. J., 2010, 16, 568. (c) K. Komatsu, Y. Urano, H. Kojima and T. Nagano, J. Am. Chem. Soc., 2007, 129, 13447.

653 (a) H. Furuta, H. Maeda, A. Osuka, Chem. Commun., 2002, 1795. (b) A. Srinivasan, H. Furuta, Acc. Chem. Res., 2005, 38, 10. (c) I. Gupta, A. Srinivasan, T. Morimoto, M. Toganoh, H. Furuta, Angew. Chem. Int. Ed., 2008, 47, 4563. (d) Y.-S. Xie, K. Yamaguchi, M. Toganoh, H. Uno, M. Suzuki, S. Mori, S. Saito, A. Osuka, H. Furuta, Angew. Chem. Int. Ed., 2009, 48, 5496. (e) M. Toganoh and H. Furuta, in Handbook of Porphyrin Science: With Applications to Chemistry, Physics, Materials Science, Engineering, Biology and Medicine, eds. K. M. Kadish, K. M. Smith, R. Guilard, World Scientific, New Jersey, 2010, ch. 10, vol. 2, pp. 295-367.

754 (a) A. Srinivasan, T. Ishizuka, A. Osuka and H. Furuta, J. Am. Chem. Soc., 2003, 125, 878. (b) I. Mayer, K. Nakamura, A. Srinivasan, H Furuta and K. Araki, J. Porphyrins Phthalocyanines, 2005, 9, 813. (c) M. Suzuki, M.-C. Yoon, D. Y. Kim, J. H. Kwon, H. Furuta, D. Kim and A. Osuka, Chem. Eur. J., 2006, 12, 1754. (d) J. H. Kwon, T. 80 K. Ahn, M.-C. Yoon, D. Y. Kim, M. K. Koh, D. Kim, H. Furuta, M Suzuki and A. Osuka, J. Phys. Chem., B 2006, 110, 11683. (e) J.-H. Ryu, T. Nagamura, Y. Nagai, R. Matsumoto, H. Furuta and K. Nakamura, Mol. Cryst. Liq. Cryst., 2006, 445, 249. (f) J.-H. Ryu, T. Nagamura, H. Furuta and K. Nakamura, J. Photopolym. Sci. Technol., 2006, 19, 15. (g) J.-H. Ryu, F. Ito, T. Nagamura, K. Nakamura, H. Furuta, Y. Shibata and S. Ito, Chem. Phys. Lett., 2007, 443, 274. (h) J. M. Lim, J. S. Lee, K. S. Kim, K. Yamahuchi, M. Toganoh, H. Furuta and D. Kim, Chem. Commun. in press.

5 (a) C. W. Tornøe, C. Christensen and M. Meldal, J. Org. Chem., 2002, 67, 3057. (b) V. V. Rostovtsev, L. G. Green, V. V. Fokin and K. B. Sharpless, Angew. Chem. Int. Ed., 2002, 41, 2596. (c) T. R. Chan, R. Hilgraf, K. B. Sharpless and V. V. Fokin, Org. Lett., 2004, 6, 2853.

6 See Electronic supplementary information (ESI).

957 Y. Ikawa, H. Harada, M. Toganoh and H. Furuta, Bioorg. Med. Chem. Lett., 2009, 19, 2448.

8 See the inset of Fig. 2a.

9 Switch-off type NIR fluorescent sensing for $\mathrm{Hg}^{2+}$ and $\mathrm{Ag}^{+}$in methanol using meso-aryl [26] hexaphyrins was reported. (a) X.-J. 100 Zhu, S.-T. Fu, W.-K. Wong, J.-P. Guo and W.-Y. Wong, Angew. Chem. Int. Ed., 2006, 45, 3150. (b) X. Zhu, S. Fu, W.-K. Wong and W.-Y. Wong, Tetrahedron Lett., 2008, 49, 1843.

10 Preliminarily experiments show the dissociation constant of bis- $\mathrm{Zn}^{2+}$ complex of $\mathbf{N}_{2} \mathbf{C H}-\mathbf{R 8}$ is less than $6 \times 10^{-6}\left(\mathrm{M}^{2}\right)$ and the fluorescence quantum yield is of the order of $10^{-3}$ in aqueous solution.

11 A. I. Bush, Curr. Opin. Chem. Biol., 2000, 4, 184.

12 (a) S. F. Dowdy, in Handbook of Cell-Penetrating Peptides $2^{\text {nd }}$ Ed. ed., Ü. Langel, Taylor \& Francis, Boca Raton, 2002, p. 309. (b) S. Futaki, Biopolymers, 2006, 84, 241. 